\title{
THE ICES WORKING GROUP ON OCEANIC HYDROGRAPHY: BUILDING ON OVER 100 YEARS OF NORTH ATLANTIC OBSERVATIONS
}

\author{
N.P. Holliday ${ }^{(1)}$, H. Valdimarsson ${ }^{(2)}$, G. Nolan $^{(3)}$, S.L. Hughe ${ }^{(4)}$, \\ A. Lavín ${ }^{5)}$, S. Østerhus ${ }^{(6)}$, T. Sherwin ${ }^{(7)}$, A. Trofimov ${ }^{(8)}$ \\ (1) National Oceanography Centre, Southampton, Waterfront Campus, European Way, Southampton SO14 3ZH, \\ United Kingdom, Email: penny.holliday@noc.soton.ac.uk \\ ${ }^{(2)}$ Marine Research Institute, PO Box 1390, Skulagata 2, 121 Reykjavic, Iceland, Email: hv@ @afro.is \\ ${ }^{(3)}$ Marine Institute, Rinville, Oranmore, Co. Galway, Ireland, Email: glenn.nolan@marine.ie \\ (4) Marine Scotland, Marine Laboratory, PO Box 101, 375 Victoria Road, Aberdeen, AB11 9DB, Scotland, \\ United Kingdom, Email: s.hughes@marlab.ac.uk \\ ${ }^{(5)}$ Instituto Español de Oceanografía, Apdo 240, 39080 Santander, Spain, Email: alicia.lavin@st.ieo.es

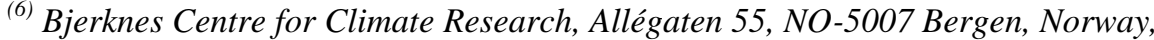 \\ Email: Svein.Osterhus@bjerknes.uib.no \\ (7) Scottish Association for Marine Science, Dunstaffnage Marine Laboratory, Oban, Argyll, PA37 1QA, Scotland, \\ United Kingdom, Email: toby.sherwin@sams.ac.uk \\ ${ }^{(8)}$ Knipovich Polar Research Institute of Marine Fisheries and Oceanography (PINRO), 6 Knipovich Street, Murmansk \\ 183038, Russia, Email: trofimov@pinro.ru
}

\begin{abstract}
The ICES (International Council for the Exploration of the Sea) Working Group on Oceanic Hydrography (WGOH) maintains, analyses and develops coastal, shelf and deep ocean repeated stations and sections around the subpolar North Atlantic, the Nordic Seas and adjacent shelf seas. The WGOH annually reviews the latest results and research from repeat hydrography sections and stations, and generates a summary of hydrographic conditions in the North Atlantic, the ICES Report on Ocean Climate (IROC).
\end{abstract}

By combining expertise in variability in physical processes and the relationship with ecosystems from around the North Atlantic, the WGOH is an excellent forum for developing new insight into climate variability and the impact on ecosystems. Recent new collaborative research highlights include observations of unusually warm and saline Atlantic Water in the Nordic Seas, a comparison of gridded sea surface temperature products to selected time series, and an isopycnal analysis over 300,000 profiles from the Nordic Seas.

The WGOH encourages development of new time series and the use of new technology, and has led to the establishment of new ADCP (Acoustic Doppler Current Profiler) and surface observations from voluntary observing ships. Future challenges for $\mathrm{WGOH}$ include maintaining the integrity of time series, and communicating the information from the time series in a useful way to a wide range of stakeholders.

The ICES WGOH has no dedicated funding, instead participants and time series are funded by member nations which are Canada, Denmark, Estonia, Faroes, Finland, France, Germany, Iceland, Ireland,
Netherlands, Norway, Poland, Portugal, Russia, Spain, Sweden, UK and USA.

\section{INTRODUCTION}

The International Council for the Exploration of the Sea (ICES) was established in 1902 to "promote and encourage research ... for the study of the sea, particularly the living resources thereof", with a focus on the North Atlantic and adjacent seas. It is a regional, intergovernmental organisation, and it provides advice to governments and other bodies on such matters as fisheries and pollution. The physics of ocean circulation and the long-term variability in ocean climate has always been important to ICES, and takes place within the ICES Working Group on Oceanic Hydrography (WGOH). The Group analyses the most recent observations of the deep ocean and adjacent deep and shallow basins: the North Atlantic and Nordic (Greenland, Iceland and Norwegian) Seas, and the Labrador, Barents, Baltic and North Seas. Typically data are presented that are only months or even weeks old, making this an excellent forum for understanding the present physical state of the ocean. Each new data set is presented in the context of long-term observations; some records go back 100 years. With data spread across the region, the $\mathrm{WGOH}$ is also in a good position to understand the basin-scale processes that link individual time series. A WGOH collaborative paper [1] showed that recent unusually warm and saline North Atlantic water from the subpolar gyre could be traced through the Nordic Seas to the Fram Strait where it enters the Arctic ocean.

The members of the WGOH are research and fisheries scientists dedicated to making high quality measurements and using them to understand how the 
ocean works. Current research being undertaken by members covers a wide range of topics from surface processes to deep overflows, across the North Atlantic from the western deep ocean basins to the wide eastern shelf seas, and from the subtropical gyre to the Arctic [2-14]. The focus is on interannual to decadal variability, including the mechanisms that determine properties and transports [1], [12-20]. A particular feature of research within the WGOH is the links between physical conditions and biological systems [2126]. The use of new technology is a further strength of research within the WGOH [27] and 28].

\section{THE OBSERVING NETWORK}

The observing network that is analysed and maintained by the $\mathrm{WGOH}$ is characterised by numerous short hydrographic sections, time series stations and a small number of basin-scale coast-to-coast sections (Fig. 1). The sections and stations are typically sampled from 1 to 4 times per year, though some stations are sampled as much as daily or weekly. Many have chemical and biological observations associated with them and are analysed in an ecosystem context. The WGOH includes time series that are over 100 years long; for example, the Faroe-Shetland Channel sections began in 1893, and the Kola section in the Barents Sea began in 1900. The most frequently-occupied, long, deep ocean time series is at Ocean Weather Station "M" in the Norwegian Sea, which started in 1948.

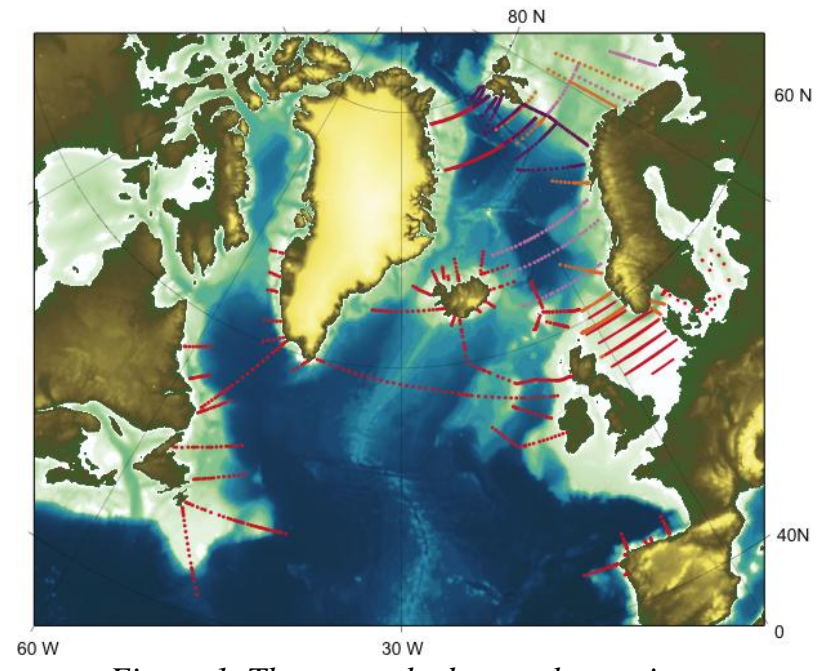

Figure 1. The repeat hydrography sections and stations of the ICES WGOH.

In addition to the illustrated sections, the WGOH utilises opportunistic data from academic research cruises and fisheries surveys to understand variability and physical processes. These additional data are a crucial, varying resource, which cannot easily be shown on a schematic map. For example, by combining Nordic Seas data from the ICES data centre and PINRO (Murmansk-based Polar Scientific Institute for Fishery and Oceanography) in Murmansk, Russia, the WGOH were able to analyse over 300,000 temperature and salinity profiles for the 1951-2000 period (Fig. 2 [29]). The analysis of data on isopycnal surfaces showed property variations that are significantly different to those on a depth surface.

A further resource are data collected by voluntary observing ships which measure temperature and salinity with XBTs and thermosalinographs, and ocean currents with ADCPs. The results from monthly sampling of surface and bottom temperatures for nearly three decades in the Mid Atlantic Bight reveal the power of systematic or repeat sampling from merchant marine vessels.

The WGOH actively encourages the development of the observing network, including the establishment and reporting of new time series. One example is a new group of repeated hydrographic sections run by Ireland on the NW European continental shelf, which were developed in consultation with the WGOH. Another recent example is the instrumenting of a Faroese ferry, $M V$ Norrona, with a thermosalinograph and ADCP, in order to collect data along its routes across the North Sea and the deep North Atlantic. The WGOH also supports the revival of long time series, which have suffered a hiatus in data collection through a lack of funding. For example a recent new member will bring data from a time series station in the English Channel to the forum; the series was begun in 1903, but has a gap from 1985-2002 when funding was withdrawn. By including the new member and time series, the WGOH will aid the analysis of the recent station data, and improve regional understanding by synthesising all available data.

\section{COMMUNICATING INFORMATION}

Each year the WGOH generates a co-operative research report that summarises the physical conditions in the North Atlantic and Nordic Seas. The ICES Report on Ocean Climate (IROC) describes the status of sea temperature and salinity during the previous year, as well as observed trends over the last decade or longer. Information from the longest time series provides an overview of temperature and salinity changes in the ICES area (Fig. 3). The IROC can be found at www.ices.dk/marineworld/oceanclimate.asp.

Horizontal fields of North Atlantic ocean temperature and salinity at various depths $(10 \mathrm{~m}, 300 \mathrm{~m}, 1000 \mathrm{~m})$, and mixed layer depths are provided for recent years. The maps are generated from in situ data (including Argo float temperature and salinity profiles) and satellite data. These products are extremely useful for placing the scattered time series into regional context, as well as providing new views of interannual variability. 
The main body of the IROC consists of detailed descriptions and figures describing the individual time series (Fig. 4). Data are sometimes presented as

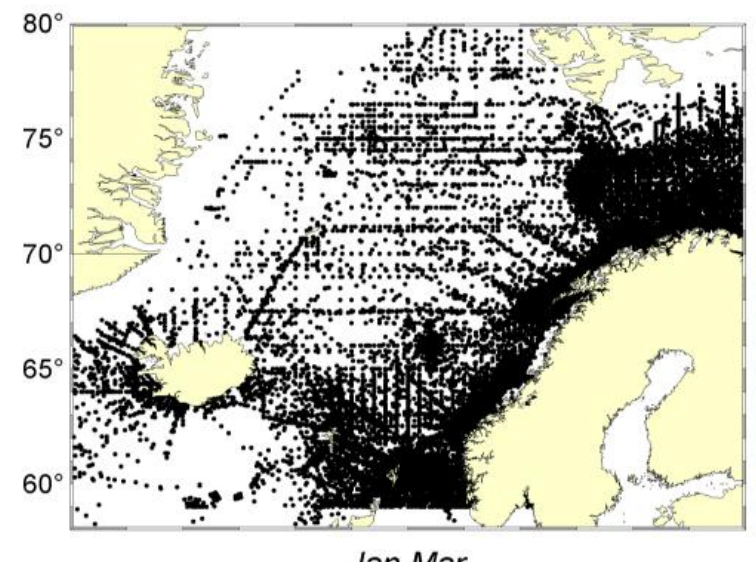

Jan-Mar

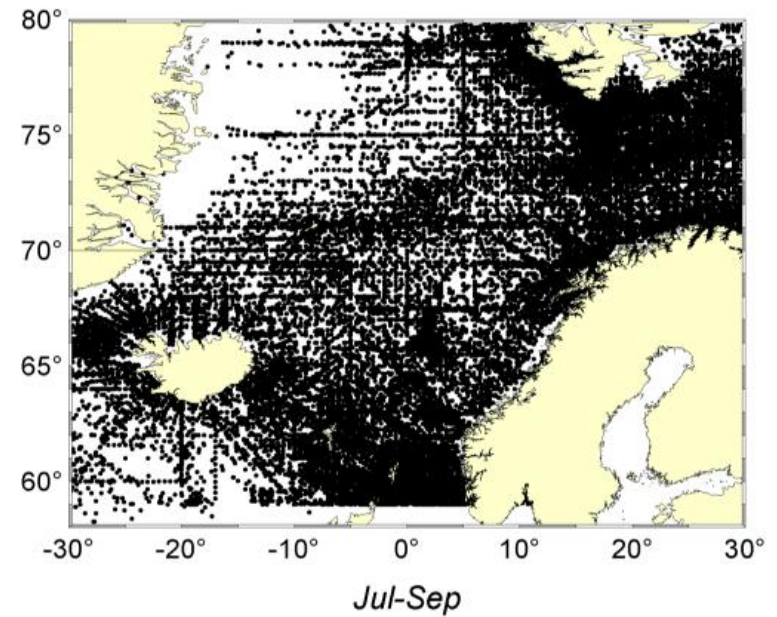

anomalies from monthly or seasonal means, since the seasonal cycle has a much higher amplitude than the interannual variability. Where data resolution permits,

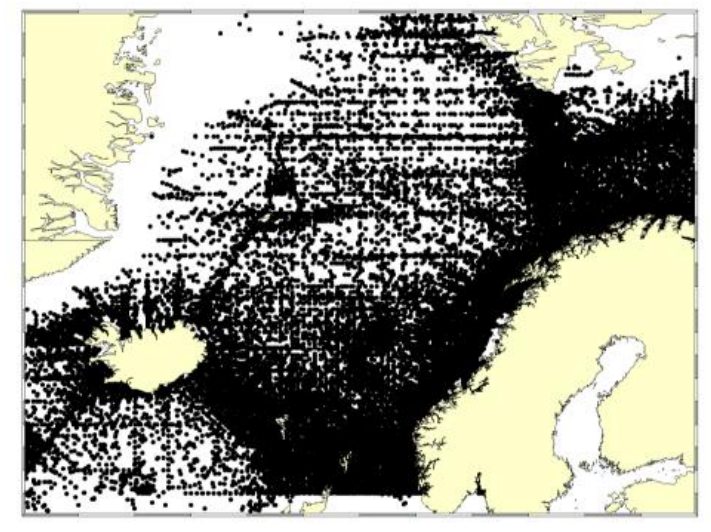

Apr-Jun

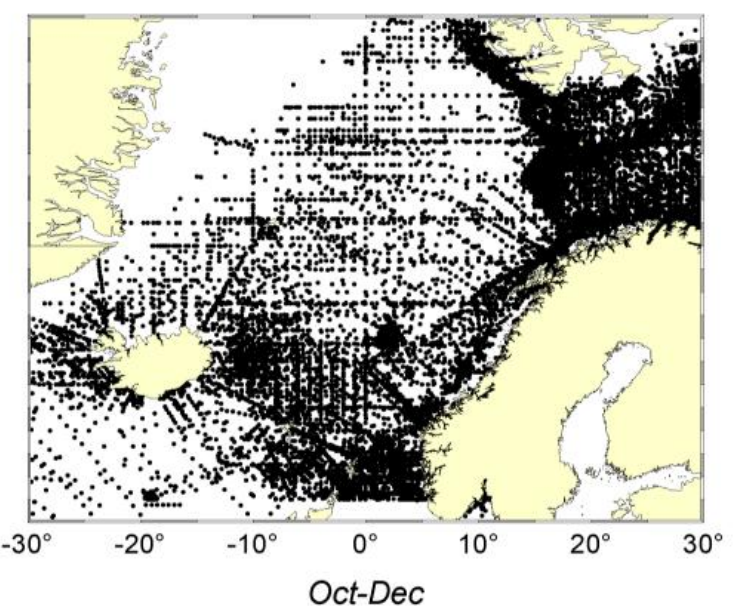

Figure 2. Hydrographic data from ICES data centre and PINRO, Russia, for the period 1950-2000 grouped according to season [29].

the most recent observations are plotted against longterm monthly means.

Recent developments in the content of the IROC include improving the information about the deep ocean. The main focus of the IROC has been the upper ocean, but significant changes occur at intermediate and deep levels too, and these have fundamental influences on circulation and ecosystems. Many of the time series sample the abyssal ocean and the WGOH is consolidating these data to provide an overview of recent conditions at depth.

The WGOH communicates data and information to the ICES stakeholders, policymakers and the broader research community. There is a wide range of level of expertise, which the $\mathrm{WGOH}$ needs to consider. The IROC is one route, primarily aimed at scientists with a range of understanding of physical oceanography. The
WGOH contributed to the production of a climaterelated brochure [31], which is aimed at all ICES stakeholders, including non-experts. The WGOH also communicates research results in annual meeting reports, through presentations at conferences, and through refereed publications. A recent comparison of gridded sea surface temperature products with some WGOH time series should provide guidance to researchers using the products for their analyses [32]. All WGOH data are archived at national data centres and in the ICES data centre.

\section{FUTURE PLANS AND CHALLENGES}

1. It is of vital importance that the existing time series are maintained. For many time series, there is a lack of funding security; most are maintained through a rolling programme of grants for a short number of years. Many time series face funding shortages periodically, especially during times when the 

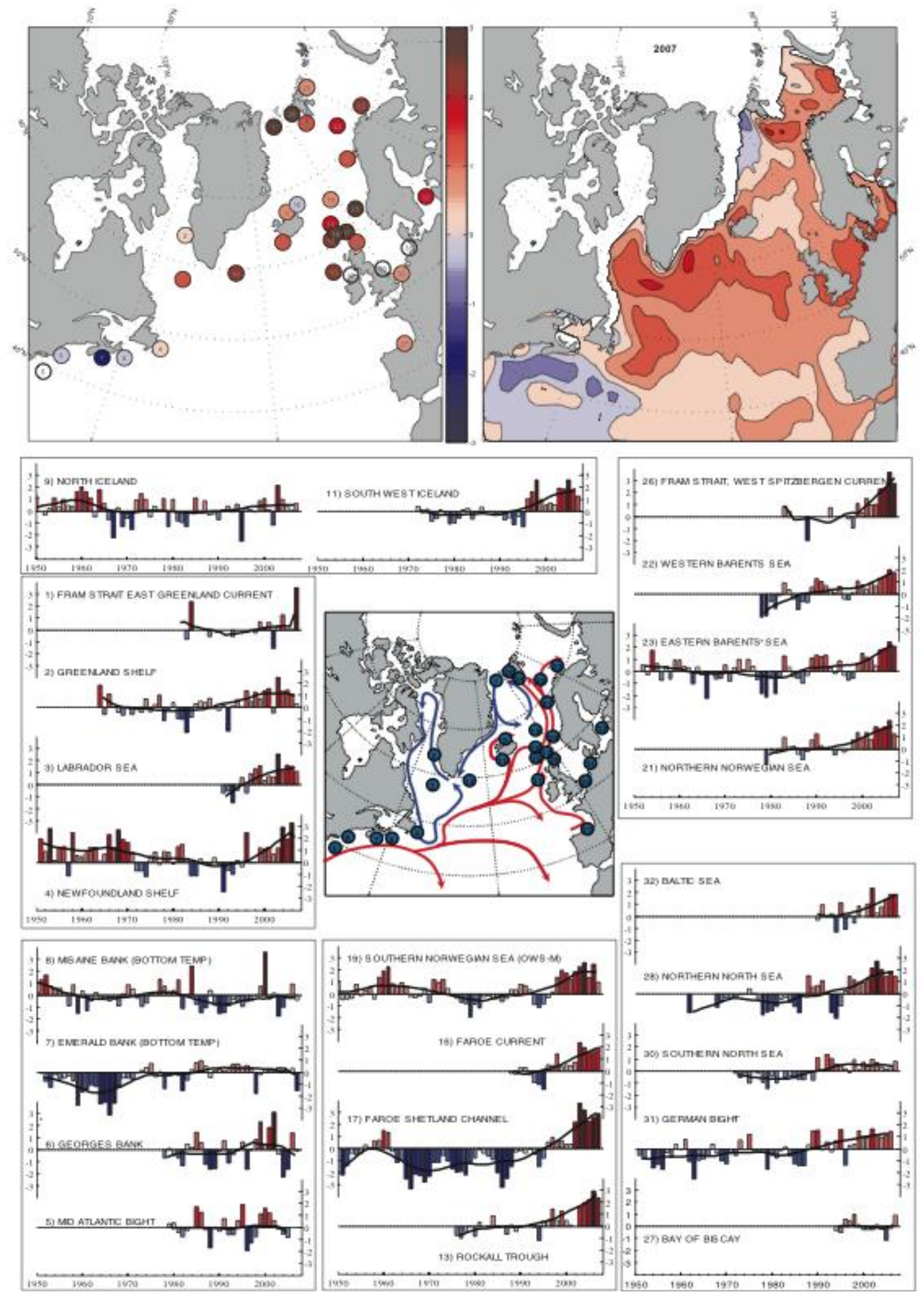

Figure 3. The IROC North Atlantic upper ocean temperature overview

(Fig. 1 from IROC 2007 [30], see report for full caption). 

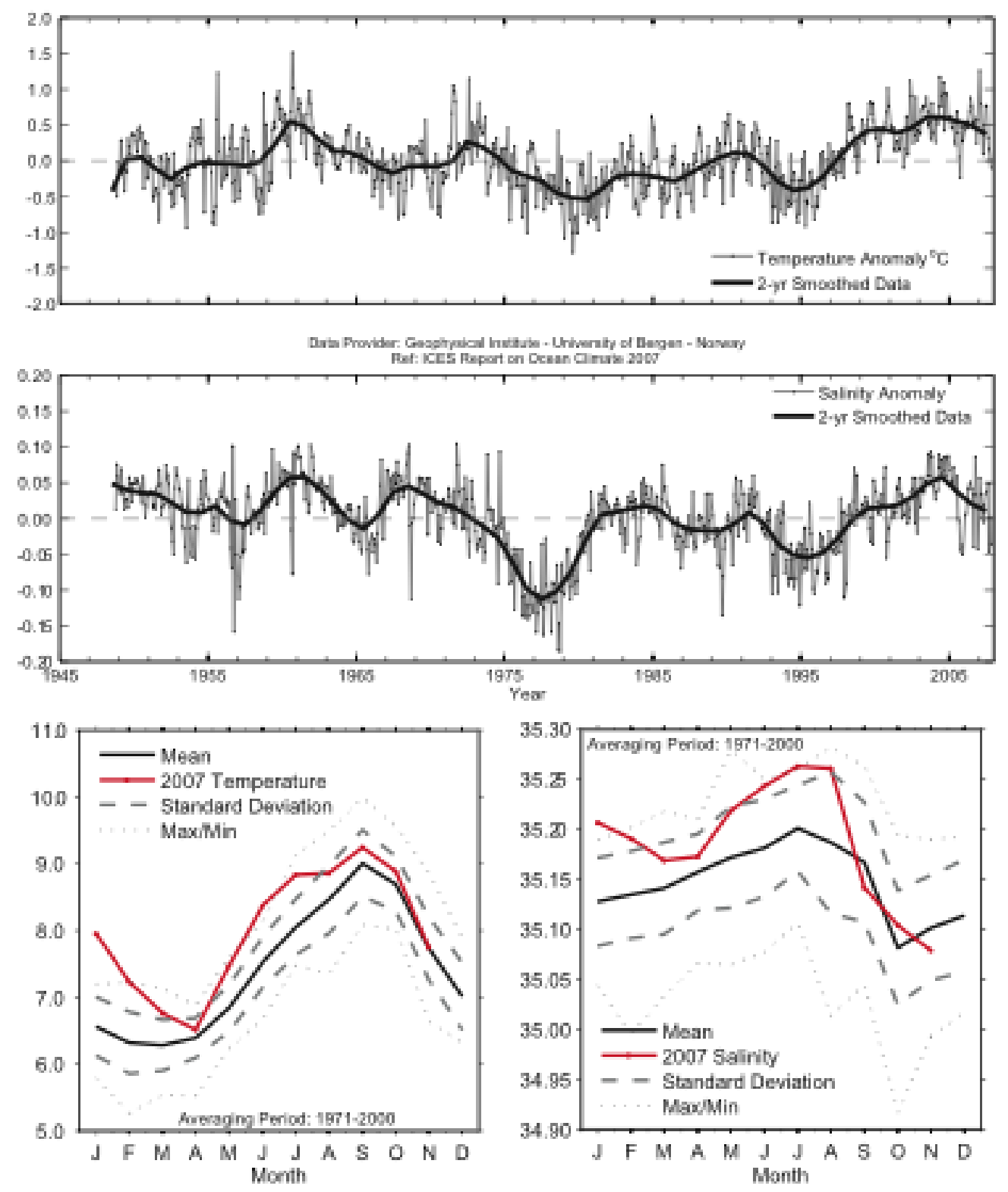

Figure 4. Norwegian Sea temperature and salinity anomalies, and monthly temperature and salinity at $50 \mathrm{~m}$ at Ocean Weather Station " $M$ " (66 $\left.{ }^{\circ} 2^{\circ} \mathrm{E}\right)$ (Figs. 57 and 58 from IROC 2007[30])

political climate turns against ocean monitoring. Some series have suffered major gaps as a result, and some have reduced temporal resolution in recent years.

2. It is also vital to maintain the continuity and integrity of the time series, to ensure that future observed changes are not artefacts of the instrumentation or platform used to make the measurements. The use of remote and autonomous instruments and vehicles is already increasing (moored profilers, floats, gliders etc), and it is anticipated that these methods will enhance shipbased measurements and in places will replace them. It is essential that a change in technology is brought in with a sufficient assessment period to avoid continuity problems.

3. The WGOH is dedicated to improving access to data and information and there remain some challenges to resolve. One objective of the IROC is to alert the research community to the wealth of data and analysis available. This approach has been reasonably successful, with the IROC being cited in an increasing number of reports and published papers. The $\mathrm{WGOH}$ is continually seeking new ways to promote their data resource and to communicate their research activities. All WGOH data are archived in national data centres, and some proportion, but by no means all, are archived in 
international data centres such as ICES and WODC. The WGOH aims to increase the amount of data being routinely sent to ICES and WODC, and to assist the ICES data centre in making their archives more easily accessible. Finally, few data collected by $\mathrm{WGOH}$ members are transmitted in real-time or near real-time; the challenge for members is to increase this activity.

4. The WGOH is a key component within the ecosystem approach adopted by ICES for fisheries advice and management. One challenge is to continue providing information in a form that is accessible and useful. A further major challenge is to generate the research that will improve the understanding of ecosystem variability.

\section{REFERENCES}

1. Holliday NP, Hughes SL, Bacon S, et al. (2008). Reversal of the 1960s to 1990s freshening trend in the northeast North Atlantic and Nordic Seas, Geophysical Research Letters, 35, L03614.

2. Bracco A, Pedlosky J, Pickart RS, 2008, Eddy formation near the West coast of Greenland, Journal of Physical Oceanography, 38, 1992-2002.

3. Hunegnaw A, Siegismund F, Hipkin R, et al., 2009, Absolute flow field estimation for the Nordic seas from combined gravimetric, altimetric, and in situ data, Journal of Geophysical Research-Oceans, 114, C02022.

4. Jeansson E, Jutterstroem S, Rudels B, et al., 2008, Sources to the East Greenland Current and its contribution to the Denmark Strait Overflow, Progress in Oceanography, 78, 12-28.

5. Kuzmina NP, Zhurbas VM, Rudels B, et al., 2008, Role of eddies and intrusions in the exchange processes in the Baltic halocline, Oceanology, 48, 149-158.

6. Larsen KMH, Hansen B, Svendsen H, 2008, Faroe Shelf Water, Continental Shelf Research, 28, 1754-1768.

7. Marnela, M.; Rudels, B.; Olsson, A. et al. (2008). Transports of Nordic Seas water masses and excess SF6 through Fram Strait to the Arctic Ocean. Progress in Oceanography. 78 (1) s. 1-11. doi:10.1016/j.pocean.2007.06.004.

8. Nilsson J, Bjork G, Rudels B, et al., 2008, Liquid freshwater transport and Polar Surface Water characteristics in the East Greenland Current during the AO-02 Oden expedition, Progress in Oceanography, 78, 45-57, doi:10.1016/j.pocean.2007.06.002.

9. Sherwin TJ, Hughes SL, Turrell WR, et al., 2008, Winddriven monthly variations in transport and the flow field in the Faroe-Shetland Channel, Polar Research, 27, $7-$ 22.
10. Soiland H, Prater MD, Rossby T, 2008, Rigid topographic control of currents in the Nordic Seas, Geophysical Research Letters, 35, L18607.

11. Våge K, Pickart RS, Moore GWK, et al., 2008, Winter mixed layer development in the central Irminger sea: The effect of strong, intermittent wind events, Journal of Physical Oceanography, 38, 41-565.

12. van Aken HM, 2008a, Variability of the water temperature in the western Wadden Sea on tidal to centennial time scales, Journal of Sea Research, 60(4), 227-234

13. van Aken HM, 2008b, Variability of the salinity in the western Wadden Sea on tidal to centennial time scales, Journal of Sea Research, 59(3), 121-132.

14. Woityra W, Rossby T , 2008, Current broadening as a mechanism for anticyclogenesis at the Northwest Corner of the North Atlantic Current, Geophysical Research Letters, 35, L05609.

15. Fontan A, Valencia V, Borja A, et al., 2008, Oceanometeorological conditions and coupling in the southeastern Bay of Biscay, for the period 2001-2005: A comparison with the past two decades, Journal of Marine Systems, 72, 167-177.

16. Gammelsrod T, Leikvin O, Lien V, et al., 2009, Mass and heat transports in the NE Barents Sea: Observations and models, Journal of Marine Systems, 75, 56-69.

17. Olsen SM, Hansen B, Quadfasel D, et al., 2008, Observed and modelled stability of overflow across the GreenlandScotland ridge, Nature, 455, 519-522.

18. Somavilla R, Gonzalez-Pola C, Rodriguez C, et al., 2009, Large changes in the hydrographic structure of the Bay of Biscay after the extreme mixing of winter 2005, Journal of Geophysical Research-Oceans, 114, C01001.

19. Sutherland DA, Pickart RS, 2008, The East Greenland Coastal Current: Structure, variability, and forcing, Progress in Oceanography, 78, 58-77.

20. Våge K, Pickart RS, Thierry V, et al., 2009, Surprising return of deep convection to the subpolar North Atlantic Ocean in winter 2007-2008, Nature Geoscience, 2, 6772.

21. Bresnan E, Hay S, Hughes SL, et al., 2009, Seasonal and interannual variation in the phytoplankton community in the north east of Scotland, Journal of Sea Research, 61, 17-25.

22. Borja A, Fontan A, Saenz J, et al., 2008, Climate, oceanography, and recruitment: the case of the Bay of Biscay anchovy (Engraulis encrasicolus), Fisheries Oceanography, 17, 477-493.

23. Debes H, Gaard E, Hansen B, 2008 Primary production on the Faroe shelf: Temporal variability and environmental influences, Journal of Marine Systems, 74, 686-697.

24. Ellingsen IH, Dalpadado P, Slagstad D, et al., 2008, Impact of climatic change on the biological production in the Barents Sea, Climate Change, 87, 155-175.

25. Madsen ML, Gaard E, Hansen BW, 2008, Wax-ester mobilization by female Calanus finmarchicus (Gunnerus) during spring ascendance and advection to 
the Faroe Shelf, ICES Journal of Marine Science, $\mathbf{6 5}$, 1112-1121.

26. Revilla M, Franco J, Bald J, et al., 2009, Assessment of the phytoplankton ecological status in the Basque coast (northern Spain) according to the European Water Framework Directive, Journal of Sea Research, 61, 6067.

27. Gaillard F, Autret E, Thierry V, et al., 2009, Quality Control of Large Argo Datasets, Journal of Atmospheric Oceanic Technology, 26, 337-351.

28. Hardman-Mountford NJ, Moore G, Bakker DCE, et al., 2008, An operational monitoring system to provide indicators of CO2-related variables in the ocean, ICES Journal of Marine Science, 65, 1498-1503.

29. Rossby T, Ozhigin, V., Ivshin, V., Bacon, S., 2009: An isopycnal view of the Nordic Seas Hydrography with focus on properties of the Lofoten Basin. Deep Sea Research, Part I: Oceanographic Research Papers Volume 56, Issue 11, Pages 1955-1971, doi:10.1016/j.dsr.2009.07.005

30. Hughes S.L., Holliday, N.P. and Beszczynska-Möller, A., 2008, ICES Report on Ocean Climate 2007, ICES Cooperative Research Report, 291, 64 pp.

31. ICES 2008: "Climate Change: changing oceans", 12pp, International Council for the Exploration of the Sea, 2008.

32. Hughes S.L., Holliday, N.P., Colbourne, E., et al, 2009. Comparison of in situ time-series of temperature with gridded sea-surface temperature data sets in the North Atlantic. ICES Journal of Marine Science, 66(7), 14671479. 